\title{
Problematika skupinové koheze v psychologii sportu
}

\section{Issues of group cohesion in sport psychology}

\author{
Pavol Šiška, Pavel Slepička
}

Fakulta tělesné výchovy a sportu Univerzity Karlovy, Praha

\begin{abstract}
Abstrakt
Článek se zabývá problematikou skupinové koheze, a to jak z obecného sociálně psychologického pohle$d u$, tak z pohledu psychologie sportu, kde jsou otázky skupinové koheze často spojovány se skupinovým výkonem. Je věnována pozornost zejména teoretickým př́stupưm k problematice skupinové koheze, kde se ukazuje rozmanitost chápání a definování koheze jako skupinového jevu. Autoři se také zabývají důležitostí koheze v oblasti sportu, kdy zejména kolektivni sporty vytvářejí nejvhodnější predpoklady pro pưsobeni koheze jako faktoru modifikujícího výkon sportovních družstev. V článku jsou prezentovány i možnosti diagnostiky koheze využitelné ve sportovní praxi a je provedeno srovnání výsledků studií různých autorů používajících uvedené metody v oblasti sportu. V závěru jsou naznačeny další možnosti zkoumání tohoto jevu, který nebývá častým predmètem zkoumání v našich podmínkách.
\end{abstract}

\begin{abstract}
Abstrakt
The article presents a review of research on group cohesion; an important social-psychological construct especially relevant to sport psychology where group cohesion is often considered as a crucial factor in the performance of sport teams. First, the article focuses on theoretical approaches to a delimitation of group cohesion as a diverse construct which has been defined in various ways. The article also shows the importance of cohesion and its dynamics in the field of sport where especially the performance in the team sports seems to be directly related to the relative level of group cohesion. Furthermore, the article presents diagnostic possibilities of group cohesion useful in coaching practice and compares the results of various research applications of these methods in the field of sport. Finally, the authors suggest possible directions in further research of this construct which has not been sufficiently studied in the Czech context.
\end{abstract}

Klícová slova: $\quad$ sport, skupina, skupinová dynamika, týmová koheze

Keywords: $\quad$ sport, group, group dynamics, team cohesion

Tento výstup vznikl v rámci projektu Specifického vysokoškolského výzkumu 2011-263602 a s podporou výzkumného zámèru VZ MŠMT ČR MSM 0021620864.

\section{Úvod}

Problematika skupinové koheze patř́ k frekventované tematice jak v oblasti sociologie, tak v sociální psychologii, a vzhledem k tendenci nalézat a analyzovat psychosociální faktory skupinového výkonu postupně př̀šla i do psychologie sportu.

Obecně lze konstatovat, že skupinová koheze (soudržnost) jako skupinový jev má svou poznatkovou historii vycházející zejména z pohledu na skupinu jako na dynamický systém pozic, rolí a vzájemných vztahů jednotlivých členů postavených na emocionálním základě.

Při pohledu na kohezi jako skupinový jev je možné nalézt přístupy vycházející spíše ze sociologického pohledu a př́istupy akcentující hledisko sociálně psychologické. Proto lze nalézt různé definice pojmu koheze. Carron et al. (2005) uvádí, že rozdíly v definování kohezivity odráží odlišné pohledy na tento komplexní konstrukt a ukazují problémy při definovaní jakéhokoli teoretického pojmu, který je abstrakcí, a nebývá přímo pozorovatelný. 


\section{Vymezení pojmu koheze}

Sociologické pohledy na kohezi jako skupinový jev vychází většinou ze sociometrické orientace a soudržnost propojují s rozvojem vzájemných vazeb ve skupině založených na vzájemné sympatii (Adrejevová, 1984). Tento př́stup vyústil i v koncipování indexu skupinové soudržnosti, který je spí̌̌e kvantitativní charakteristikou skupiny, nepostihující kvalitativní stránku soudržnosti.

Př́stup sociálně psychologický se odráží například v př́stupu Festingera, Schactera a Backa (1950). Ten vychází zejména $\mathrm{z}$ analýzy komunikačních vazeb ve skupině a definuje soudržnost jako sumu všech sil, které působí na členy skupiny, tak aby v ní zůstaly. Za síly držící členy ve skupině byly považovány jak míra atraktivity skupiny pro její členy, tak spokojenost jedinců se členstvím ve skupině. V tomto pojetí se objevuje již i kvalitativní hledisko, akceptující prožitek ze členství jako faktor ovlivňující kohezi.

S obdobným pohledem přichází i Newcombe (1961), který vytváří pojem „konsenzu“ a dále s ním operuje při definování koheze. Předpokládá při tom nezbytnost vzniku konsenzu ohledně orientací jednotlivých členů ve vztahu k významným hodnotám. Dosažení konsenzu podle něj vede k redukci skupinového napětí plynoucího z případných citových reakcí jednotlivých členů. I v tomto případě hraje důležitou roli emocionální aspekt soudržnosti.

Další autoři, např. Gross and Martin (1952), zastávají názor, že kohezi je možné definovat jako odolnost skupiny vůči rušivým silám.

Jiný př́stup je patrný u autorů Carrona et al. (1998), kteří definují skupinovou kohezi jako dynamicky proces, který se odráží v tendenci skupiny držet pohromadě a zůstat jednotnou při snaze o dosažení společných cílů a/nebo při uspokojování emočních potřeb jednotlivých členů. Toto chápání koheze vymezuje i čtyři její základní charakteristiky.

Jednou z nich je multidimenzionalita vyjadřující, že koheze není jeden faktor, ale spíše komplex několika vzájemně souvisejících faktorů, které se mohou v jednotlivých skupinách lišit (Schneider, Gruman \& Coutts 2005; Carron, 2005). Například hráči zůstávají v družstvu, protože mají pozitivní emocionální vztahy se spoluhráči, prŕípadně $\mathrm{k}$ trenérovi, protože působení v družstvu jim dává př́íležitost dosáhnout úspěch, nebo nemají jinou možnost k provozování sportu.

Druhou charakteristikou soudržnosti podle citovaných autorů je dynamika. Ta vyjadřuje skutečnost, že koheze je dynamický jev, měnící intenzitu a úroveň, např́klad v průběhu sportovní sezony, v sociální a úlohové kohezi, nebo v průběhu procesu formovaní, udržování a rozpadu sportovní skupiny.

Instrumentalita je třetí charakteristikou koheze. Carron (2005) upozorňuje, že skupiny se tvoří s nějakým účelem, což platí jak pro sportovní skupiny, tak pro skupiny pracovní či vojenské, nebot jsou všechny tvořeny $\mathrm{z}$ různých úlohově orientovaných důvodů. Úkoly a cíle jsou hlavní faktory, které udržují skupiny jednotné.

Soudržnost má i emoční charakteristiku, tzv. „affective dimension“. Schneider, Gruman a Coutts (2005) tvrdí, že nelze pochopit podstatu soudržnosti bez respektování skutečnosti, že vzájemné emoční vztahy jsou podstatnou součástí sil držících skupinu pohromadě. Skupina bez zastoupení emoční dimenze se vyznačuje konflikty s tendencí k rozpadu (Carron at al., 2007). Emoční a instrumentální stránky koheze se obrážejí zejména ve dvou dimenzích koheze, a to v sociální a úkolové kohezi.

Při určitém schematizujícím pohledu na vývoj názorů na kohezi jako skupinový jev je možné uvažovat o třech úrovních rozvoje skupinové koheze. První úroveň rozvoje je dána rozvojem emocionálních vztahů, a koheze je pak opřena o úroveň těchto vztahů ve skupině.

Druhá úroveň je reprezentována postupnou konfigurací skupinových hodnot spjatých převážně s vlastní skupinovou činností, přičemž se očekává, že koheze vzrůstá s postupným sladováním a akceptací těchto hodnot jednotlivými členy skupiny.

Třetí úroveň souvisí s postupnou identifikací jednotlivých členů skupiny se stanovenými cíli skupinové činnosti. Soudržnost je pak vyjádřena především homogenitou cílů skupinové činnosti, které se zároveň stávají významnou složkou hodnotové orientace skupiny.

Obdobné prŕstupy jsou patrné i v rámci psychologie sportu, kde se koheze považuje za jeden $\mathrm{z}$ významných faktorů souvisejících s úspěchem zejména v kolektivních sportech (Golembiewski, 1962; Lott \& Lott, 1965). 
Carron el al. (2005) tvrdí, že vysoce soudržné sportovní družstvo bude schopno lépe zvládat značný rozsah a intenzitu zátěžových situací vyskytujících se ve sportovním prostředí, jako například prohraná utkání, kritiku medií, nedostatečné materiální vybavení ve srovnání s ostatními družstvy. Jsou akceptovány i sociálně psychologické přístupy k chápání koheze. Carron, Prapavessis \& Grove (1994), Hausenblas \& Carron (1996), Svoboda \& Vaněk (1986) ji definují jako „výsledek souboru vnitroskupinových sil působících na členy, aby ve sportovní skupině zůstali." Kačáni (1991) hovoří o soudržnosti sportovního družstva $\mathrm{v}$ př́ípadě, kdy jsou hráči ochotní a schopní dávat přednost skupinovým cílủm před cíli osobními. Důležitost koheze zdůrazňuje i Gurský (2005), který považuje kohezi za hlavní sílu udržující družstvo pohromadě. Slepička (2006) chápe soudržnost ve sportovních družstvech jako silný pocit sounáležitosti založený na intenzivních emocionálních vazbách mezi členy družstva. I v těchto přístupech je naznačená již zmíněná vrstevnatost koheze, kdy jednotlivé pohledy citovaných autorů zdůrazňují ve svých definicích některou $\mathrm{z}$ výše uvedených úrovní koheze.

Problematika koheze má vedle roviny teoretické, směřující k vytváření teoretických konceptů, i rovinu metodickou, kdy se jedná zejména o možnosti měření skupinové koheze.

\section{Možnosti měření koheze}

V psychologii sportu je možné nalézat jednak tradiční přístupy sociometrické, které opírají svou metodiku o princip výběru mezi členy skupiny a o diagnostiku vzájemných vztahů ve skupině, pokládané za základ skupinové koheze. Tyto sociometrické metodické přístupy přinášejí kvantitativní informace o struktuře vazeb ve sportovní skupině a jsou ve sportovní praxi poměrně snadno využitelné, nicméně nejsou schopné podchytit jiné, např́ílad motivační faktory ovlivňující navazování vazeb mezi jedinci ve skupině.

Vedle toho byla postupně vyvinuta řada dotazníkových metod, zaměřených na zjištování koheze, které jsou v psychologii sportu často používány a jsou schopny zachytit i další stránky skupinové koheze. Je možné uvést zejména tyto:

- Dotazník skupinové koheze (TCQ; Gruber \& Grey, 1981),

- Dotazník sportovní koheze (SCI; Yukelson, Wienberg \& Jackson, 1984),

- Dotazník skupinového prostředí (GEQ; Carron, Widmeyer \& Brawley1985),

- Dotazník skupinové psychologie (TPQ; Partington \& Shangi, 1992),

- Dotazník prostředí sportující mládeže (YSEQ; Eys, Loughead, Bray \& Carron, 2009).

Z uvedených dotazníkových metod se dočkal největšího použití již zmíněný Dotazník skupinového prostředí (GEQ, Group environment questionanaire), založený na koncepci vycházející zejména ze sociálně-kognitivní teorie lidského chování, teorie skupinové dynamiky zdůrazňující úlohovou a sociální funkci sportovního družstva jako sociální skupiny (Carron, Widmeyer \& Brawley, 1985). Tito autoři vycházejí z předpokladu, že každý člen si postupně vytváŕí názory a postoje vztahující se na skupinu jako celek, na způsob jakým skupina přispívá k saturaci jeho potřeb a cílů. Hovoří pak o:

- úkolové kohezi zaměřené na plnění skupinových úkolů a tím dosahování skupinových cílů,

- sociální kohezi souvisící s vzájemnými vztahy ve skupině, jejich tvorbou a udržováním či modifikací,

- skupinové integraci vyjadřující nakolik jedinec vnímá společné skupinové rysy vytvářející určitý stupeň vnitřního sjednocení skupiny,

- individuální přitažlivost skupiny odrážející stupeň atraktivity skupiny pro jedince i jeho emocionální prožitkovou vazbu na skupinu.

Z tohoto chápání koheze výše citovanými autory byl pak koncipován dotazník GEQ (Group environment questionnaire), zaměřený na zjištování dimenzí skupinové koheze.

Pro ilustraci uvádíme jaké součásti má podle tvůrců dotazníku Carrona, Widmeyera \& Brawleyho

(1985) skupinová koheze u sportovních družstev a jak se obrážejí v položkách dotazníku:

- skupinová integrace - úlohová (Group integration-task, GI-T): reprezentovaná 5 položkami majícími podobu hodnotících výroků (např. členové našeho družstva jsou jednotní v úsilí dosáhnout stanoveného cíle); 
- $\quad$ skupinová integrace - sociální (Group integration-social, GI-S): reprezentovaná 4 položkami (např. členové našeho družstva se zř́ídka zúčastňují společné zábavy);

- individuální atraktivita skupiny - úlohová (Individual attraction to group-task, ATG-T) obsahuje 4 položky (např. nemám rád styl hry našeho družstva);

- individuální atraktivita skupiny - sociální (Individual attraction to group-social, ATG-S) zastoupená v dotazníku 5 položkami (např. někteří z mých nejlepších přátel jsou v našem družstvu).

Celý dotazník je tvořen 18 položkami a odpovědi jsou rozloženy na 9bodové škále seřazené od silně nesouhlasím (1) až k silně souhlasím (9). Přitom vyšší dosažené skóre vyjadřuje vyšší úroveň vnímané soudržnosti.

Tuto metodu uvádíme podrobněji zejména proto, že byla metodickým nástrojem použitým u většiny zahraničních studií zabývajících se výzkumem koheze ve sportu. Předmětem zájmu byla sportovní družstva a výsledky některých z těchto studií jsou uvedeny v následující části stati věnující se problematice koheze ve sportu.

\section{Koheze ve sportu}

Sportovní praxe přináší řadu př́kladů dokumentujících skutečnost, že úspěšná sportovní družstva se vyznačují velmi dobrou hráčskou skladbou. Ta je sice nespornou, avšak nikoli postačující podmínkou úspěchu. Vrcholné sportovní soutěže mnohokrát přinesly situaci, kdy družstva složená z vynikajících hráčů, od nichž se očekával vrcholný výkon a jejichž hráčská skladba měla být zárukou úspěchu, tato očekávání nenaplnila. Ukazuje se, že k úspěchu je nutná i snaha propojit dovednosti s úsilím všech hráčů po dosažení skupinových cílů na základě vzájemné spolupráce, podmíněné mimo jiné i vhodnou skladbou vzájemných vazeb modifikujících skupinové klima.

Jako př́íklad situace, kdy se úroveň koheze promítla do výsledků fotbalového družstva, lze uvést fotbalový šampionát $\mathrm{v}$ Jižní Africe, kdy francouzské družstvo, které obhajovalo finálovou účast z předchozího šampionátu, zcela propadlo, umístilo se na posledním místě ve své základní skupině s jedním vstřeleným golem. Účinkování družstva na tomto šampionátu bylo provázeno vnitroskupinovými konflikty mezi hráči, konflikty s trenérem, bojkotem tréninků, což jednoznačně dokládá nízkou úroveň koheze.

Szreter (2004) uvádí obdobný, avšak pozitivní př́klad vlivu koheze na výkon, kdy podceňované řecké fotbalové národní družstvo vyhrálo evropský fotbalový šampionát Euro 2004. Na turnaji, na kterém se favoritům nedařilo, bylo př́iznačné, že ME nakonec vyhrál „outsider“, přičemž tento nečekaný úspěch byl připisován zejména „týmové práci“, vyjadřující vysoký stupeň koheze družstva, opřené o dobré vzájemné vztahy hráčů.

Peterson (2004) uvádí př́iklad z basketbalu, kdy úspěch družstva Detroitu v NBA byl spojen zejména s pěti faktory, za které pokládal rychlost hráčů, jejich dlouhodobě stabilizovaný zdravotní stav, herní agresivitu a inteligenci a kohezi. Uvedené př́klady ilustrují, jak veliká důležitost je ve sportovní praxi přisuzována kohezi ve vztahu ke skupinovému výkonu a následnému úspěchu v soutěži.

$\mathrm{Na}$ druhé straně je $\mathrm{v}$ psychologii sportu možno nalézt řadu studií věnujících se problematice koheze a výkonu, jejichž výsledky přinášejí spíše rozporuplné závěry. Např́íklad Lenk (1969) uvádí ve své studii, že při velkých úspěších německých veslařủ v letech 1960 a 1962 byla zjištěna nízká úroveň koheze ve veslařských skupinách. Rovněž Fox (1984) neprokázal žádný významný vztah mezi kohezí a úspěchem. Poukazoval na existenci rozporného vztahu mezi kohezí a úspěchem, protože nalezl jak pozitivní vazby mezi úrovní soudržnosti a výkonem, tak i vazby negativní, kdy vysoká úroveň soudržnosti nevedla k dobrému skupinovému výkonu.

Většina výzkumných studií však přináší poznatky o pozitivním vlivu koheze na skupinový výkon (Shangi \& Carron 1987, Carron, Mullen \& Cooper 1994; Carron, Bray \& Eys 2002, Murray 2006).

Zajímavá je zejména studie Carron, Colman, Wheeler and Stevens (2002), kteř́ provedli metaanalýzu 46 výzkumných studií, v níž sledovali vztah mezi kohezivitou sportovních družstev a jejich úspěchy v soutěžích. Ukázalo se, že existuje jistá pozitivní vazba mezi kohezí a úspěchem, přičemž tato vazba může mít různou intenzitu. Zaměřili se rovněž na to, nakolik se jimi analyzované studie zabývaly úlohovou či sociální kohezí ve vztahu k výkonu, a zjistili, že u obou existuje obdobná pozitivní vazba mezi kohezí a skupinovým výkonem. 
Zajímavé jsou i studie zabývající se výzkumem toho, jakou úlohu ve vztahu koheze a výkon sehrává druh sportu či pohlaví sportujících. Carron et al. (2002) zjistili, že vztah mezi úrovní koheze družstva a jeho výkonem je významně silnější u ženských družstev než u mužských týmů. V některých výzkumech se prokázal negativní vztah mezi úrovní koheze a výkonem v koaktivních sportech jako je bowling, cyklistika (Landers \& Lüschen, 1974). To vedlo ve svých důsledcích na jedné straně k názorům zdůrazňujícím důležitost koheze pro výkon zejména u sportů, v nichž je spolupráce podstatou činnosti, jako jsou kolektivní sportovní hry, na druhé straně k názoru, že úroveň koheze nemá tak velký vliv na výkon u sportů koaktivních, kde spolupráce je spíše druhotným faktorem. Proti tomuto názoru se staví Carron et al. (2002) výzkumem, jehož výsledky prokazovaly důležitost koheze jak pro „koaktivní“, tak „kooperativní" sporty.

V souvislosti s kohezí a výkonem se často v psychologii sportu diskutuje otázka, do jaké míry vede vyšší úroveň koheze k dobrému výkonu, či zda dobrý výkon vede k vyšší skupinové kohezi. Jinak řečeno, je dobrá skupinová soudržnost podmínkou skupinového výkonu, anebo se dá považovat spíše za výsledek dobrého skupinového výkonu? V této souvislosti lze uvést, že např. Williams \& Hacker (1982) nalezli u univerzitních ženských družstev značný vliv výkonu na soudržnost. Grieve, Whelan a Mayers (2000) na základě svých zjištění tvrdí, že výkon má větší vliv na soudržnost než soudržnost na výkon družstva. Weinberg a Gould (2007) přicházejí s názorem, že vztah mezi kohezí a výkonem je reciproční, nebot koheze podporuje výkon a dobrý výkon podporuje zvýšení koheze, která dále podporuje výkon.

\section{Osobnostní a situační faktory $\mathrm{v}$ kohezi}

Podle Carrona (2005) osobnostní faktory odrážejí individuální charakteristiky členů skupiny. Zařazuje k nim demografické atributy (pohlaví, sociální prostředí), poznávání (např. připisování zodpovědnosti, sebeznevýhodňování („self-handicapping“), individuální uspokojení a stavy (napr. stav úzkosti, deprese), chování (např. adherence).

Podle Carrona \& Dannise (2001) je jedním z nejdůležitějších faktorů spojených s rozvojem úlohové i sociální koheze individuální satisfakce plynoucí z dosazování cílů.

Často se vyskytuje i „sebeznevýhodňování“, tzv. „self-handicapping“, který reprezentuje strategické jednání využívané $\mathrm{k}$ ochraně osobnosti před důsledky selhání v důležitých situacích (Jones \& Berglas, 1978). Carron el al. (2007) uvádí př́klad takového chování, kdy hráč (např „nadhazovač v baseballu) si může stěžovat na zdravotní problémy (at již skutečné či předstírané) svým spoluhráčům před důležitým zápasem a chránit tak svoje „image“v př́ípadě svého selhání v zápase. Někteř́i autoři (Carron, Prapavessis \& Grove, 1994; Hausenblas \& Carron, 1996) poukazují na to, že vyšší skupinová koheze vede k častějšímu „sebeznevýhodňování“.

Vedle již uvedených faktorů jsou s kohezí ve sportu spojované i další, spíše situační faktory jako je významnost soutěže, velikost sportovního družstva a věková odlišnost členů družstva. Grantino \& Rainey (1988) došli k závěru, že úlohová koheze byla větší v stř̌edoškolských družstvech ve srovnání s univerzitními. Gruber \& Gray (1982) zjistili, že sociální koheze byla vyšší v basketbalových družstvech žáků základních a stř̌edních škol než v seniorských družstvech.

Co se týká velikosti skupiny, obecně se vychází z teze, že se vzrůstající velikostí skupiny se soudržnost snižuje. Na tuto skutečnost se zaměřily dva výzkumy realizované v rámci studie Widmeyer, Brawley \& Carron (1990), kteří účelově složili pro své sledování 3 a 3 rekreační basketbalová družstva z 3, 6 a 9 členů. Výsledky ukázaly, že úlohová soudržnost klesala, když se počet hráčů zvyšoval. (Sociální koheze však byla vyšší ve skupinách se šesti členy.) Druhý výzkum těchto autorů sledoval družstva v soutěži 3 proti 3 , 6 proti 6,12 proti 12 . Úroveň skupinové soudržnosti byla největší v třičlenných družstvech, se zvětšujícím se počtem členů nastal progresivní pokles koheze.

\section{Styl vedení a koheze}

Dalším z faktorů ovlivňujících kohezi ve sportovních družstvech je styl realizace vůdcovské role, zejména role trenéra. Vzhledem k tomu, že role trenéra má klíčový význam pro budování a fungování spor- 
tovního družstva, je zřejmé, že styl trenérského vedení je významným faktorem koheze. Výzkumné studie zaměřené na otázky vlivu role trenéra na skupinovou kohezi prokázaly, že vyšší úroveň tréninku, frekvence instrukčního chování trenéra, pozitivní zpětné vazby od trenéra, demokratický způsob vedení a přiměřené zaměření na sociální podporu ze strany trenéra byly spojeny s vyšší úrovní úlohové koheze (Kozub, 1993; Westre \& Weiss, 1991). Studie Ramzaninezhada a Keshtana (2009), kteří se zabývali touto problematikou v seniorských fotbalových družstvech, zjistily, že trenéŕi úspěšných družstev zahrnutých do studie vykazovali signifikantně vyšší úroveň demokratického způsobu vedení a vyšší míru sociálně orientovaného chování.

\section{Závěr}

Ve sportovní praxi a rovněž $\mathrm{v}$ psychologii sportu je, i přes existenci někdy rozporných výzkumných výsledků, v obecné rovině koheze hodnocena jako pozitivní vlastnost sportovních družstev, vytvářející předpoklady jak pro aktuální skupinový výkon, tak v delší časové perspektivě i pro úspěch v soutěži.

Nicméně stále zůstává řada otevřených otázek naznačujících možné směry budoucích výzkumných studií, zejména v prostředí České republiky, kde takto orientované výzkumy jsou spíše ojedinělé. V souladu s autory Carron et al. (2007) lze konstatovat, že výzkumný zájem je nutné soustředit na otázky spojené s vlivem sociální a úlohové koheze na výkon a na rozdílný vliv koheze na výkon v mužských a ženských sportovních družstvech. Rovněž je nezbytné orientovat pozornost i na věkové odlišnosti při vlivu koheze na výkon s využitím nejnovějších metodických přístupů umožňujících srovnání výsledků i mezinárodním měřítku.

\section{Literatura}

ANDREJEVOVÁ, G. M. (1984). Sociální psychologie. Praha: Svoboda

BEAUCHAMP, M. R., EYS, M. A. (2007). Group Dynamics in Exercise and Sport Psychology. New York: Routledge.

CARRON, A.V., WIDMEYER, W. N. \& BRAWLEY, L. R. (1985). The development of an instrument to assess cohesion in sport teams: The group environment questionnaire. Journal of Sport Psychology, 7, 244-266.

CARRON, A. V., PRAPAVESSIS, H. \& GROVE, J. R. (1994). Group effects and self-handicapping. Journal of Sport and Exercise, 16, 246-258.

CARRON, A. V., BRAWLEY, L. R. \& WIDMEYER, W. N. (1998). The measurement of cohesiveness in sport groups. In J. L. Duda (Ed.), Advances in sport and exercise

psychology measurement (pp. 213-226). Morgantown, WV: Fitness Information Technology.

CARRON, A. V. \& DANNIS, P. (2001). The sport team as an effective group. In WEINBERG S. R. \& COULD, D. Foundations of sport and exercise psychology. (4d ed.) Champaign, IL: Human Kinetics.

CARRON, A. V., BRAY, S. R. \& EYS, M. A. (2002). Team cohesion and team success in sport. Journal of Sports Sciences, 20, 119-126.

CARRON, A. V., COLMAN, M. M., WHEELER, J. \& STEVENS, D. (2002). Cohesion and performance in sport: A meta-analysis. Journal of Sport and Exercise Psychology, 24, 168-188.

CARRON, A. V., HAUSENBlAS, H. A. \& EYS, M. A. (2005). Group dynamics in sport (3 $3^{\text {rd }}$ ed.) Morgantown, WV: Fitness Information Technology.

CARRON, A. V., EYS, M. A. \& BURKE, S. M. (2007). Team Cohesion. In JOWETT, S. \& LAVALLEE, D. Social Psychology in sport. Human Kinetics, 1st edition.

EYS, M. A., LOUGHEAD, T., BRAY, S. R. \& CARRON, A. V. (2009). Development of a Cohesion Questionnaire for Youth: The Youth Sport Environment Questionnaire. Journal of Sport and Exercise Psychology, 31, 390-408.

FESTINGER, L., SCHACHTER, S. \& BACK, K. (1950). Social pressures in informal groups. New York: Harper and Brothers, In WEINBERG, S. R., \& COULD, D. (2007). Foundations of sport and exercise psychology. Human Kinetics. 
FOX, E. C. (1984). Team Cohesion, Ability and Coaches' Leadership Effectiveness as Predictors of Success in Women's Intercollegiate Softball, University of Oregon Microforms.

GRIEVE, F. G., WHELAN, J. \& MEYERS, A. (2000). An Experimental Examination of the Cohesion - Performance Relationship in an Interactive Team Sport. Journal of AppliedSport Psychology, v. 12, p. 219-235.

GOLOMBIEWSKI, R. (1962). The small group. Chicago, IL: Univerzity of Chicago.

GRANITO, J. J. \& RAINEY, G. R. (1988). Differences in cohesion between high school and college football teams and starters and nonstarters. Perceptual and Motor Skills, 66, 471-477.

GROSS, N. \& MARTIN, W. (1952). On group cohesiveness. Americal Journal of Sociology, 57, 333-546. In CARRON, A. V., HAUSENBLAS, H. A. \& EYS, M. A. (2005). Group dynamics in sport (3 $3^{\text {rd }}$ ed.). Morgantown, WV: Fitness Information Technology.

GRUBER, J. J. \& GRAY, G. R. (1981). Factor patterns of variables influencing cohesiveness at various levels of basketball competition. Research Quarterly for Exercise and Sport, 52, 19-30.

GRUBER, J. J. \& GRAY, G. R. (1982). Response to forces influencing cohesion as a function of player status and level of male varsity basketball competition. Research Quarterly for Sport and Exercise, 53, 27-36. GURSKÝ, T. (2005). Psychológia športu. Bratislava: Slovenská telovýchovná spoločnost' SZTK.

HAUSENBLAS, H. A. \& CARRON, A. V. (1996). Group cohesion and self-handicapping in female and male athletes. Journal of Sport and Exercise, 18, 132-143.

JONES, E. E. \& BERGLAS, S. (1978). Control of attributions about the through self-handicapping strategies: The appeal of alcohol and role of underachievement. Personality and Social Psychology Bulletin, 4, 200-206. In CARRON, A. V., EYS, M. \& BURKE, S. M. (2007) Team Cohesion. In JOWETT, S. \& LAVALLEE, D. Social Psychology in sport. Human Kinetics, 1st edition.

KAČANI, L. et al. (1991). Teória a didaktika športovej špecializácie - futbal. Bratislava: Univerzita Komenského, 1. vyd.

KUZUB, S. A. (1993). Exploring the relationships among coaching behavior, team Cohesion and player leadership. Unpublished doctoral dissertation, Univerzity of Houston, TX. In: CARRON, A.V., HAUSENBLAS, H.A. \& EYS, M. A. (2005). Group dynamics in sport ( $3^{\text {rd }}$ ed.) Morgantown, WV: Fitness Information Technology.

LANDERS, D. M. \& LÜSCHEN, G. (1974). Team performance outcome and cohesiveness of competitive co-acting groups. Intrenational Review of Sport Sociology, 9, 57-69.

LENK, H. (1969). Top performance despite internal conflict: An antithesis to a functional proposition. In CARRON, A. V., HAUSENBLAS, H. A. \& EYS, M. A. (2005). Group dynamics in sport (3 ${ }^{\text {rd }}$ ed.) Morgantown, WV: Fitness Information Technology.

LOTT, A. J. \& LOTT, B. E. (1965). Group cohesiveness as interpersonal attraction: A review of relationships with antecedent and consequent variables. Psychological Bulletin, 64, 259-309.

MARTENS, R., LANDERS, D. M. \& LOY, J. W. (1972). Sport cohesiveness questionaire. Washington, DC: AAHPERD Publications.

MULLEN, B. \& COOPER, C. (1994). The Relationship between Group Cohesion and Performance: an Integration. Psychological Bulletin, v. 115, p. 210-227.

MURRAY, N. P. (2006). The Differential Effect of Team cohesion and Leadership Behavior in High School Sports, Individual Differences Research, v. 4, n. 4, p. 216-225. http://www.brjb.com.br/files/ brjb_60_3200903_id1.pdf

NEWCOMB, T. M. (1961) The acquaintance process. New York: Holt. Rinehart and Winston PETERSON, R. (2004). Party of five. Retrieved August 13, 2004, from www.nba.com/finals2004/blog. html. In JOWETT, S. \& LAVALLEE, D. (2006). Social Psychology in Sport. Human Kinetics, 1st edition. RAMZANINEZHAD, R. \& KESHTAN, M. H. (2009). The relationship between coach's leadership styles and team cohesion in Iran football clubs professional league. Brazilian Journal Biomotricity, 3, 2, 111-120.

SHANGI, G. \& CARRON, A. V. (1987). Group cohesion and its relationships with performance and satisfaction among high school basketball players. Canadian Journal of Sport Science, 12, $20 \mathrm{p}$. 
SCHNEIDER, F. W, GRUMAN, J. A. \& COUTTS, L. M. (2005). Applied Social Psychology. London: Sage Publications, Inc.

SLEPIČKA, P., HOŠEK, V. \& HÁTLOVÁ, B. (2006). Psychologie sportu. Praha: Karolinum, 1. vyd. SVOBODA, B. \& VANĚK M. (1986). Psychologie sportovních her. Praha: OLYMPIA. vyd.

SZRETER, A. (2004). Greeks upset the odds again. Retrieved August 13, 2004 from http://www.euro2004. com/tournament $/$ matches/round $=1623 /$ match $=1059194 /$ Report=rw.html

ŠMICER, V. (2010). Pád fotbalové Francie? Domenech a neexistující parta [online], dostupné z http://fotbal.idnes.cz/pad-fotbalove-francie-domenech-a-neexistujici-parta-hodnoti-smicer-1dl-/ms-fotbal-2010. asp?c=A100623_115741_ms-fotbal-2010_mn

WEDMEYER, W. N., BRAWLEY, L. R. \& CARRON, A. V. (1990). The effect of group size in sport. Journal of Sport \& Exercise Psychology, 12, 177-190.

WEINBERG S. R. \& GOULD, D. (2007). Foundations of sport and exercise psychology. (4 ${ }^{\text {rd }}$ ed.) Champaign, IL: Human Kinetics.

WESTRE, K. R. \& WEISS, M. R. (1991). The relationships between perceived coaching behaviors and group cohesion in high school football teams. Sport Psychologist, 5, 41-54.

WILLIAMS, J. M. \& HACKER, C. M. (1982). Causal relationships among cohesion, satisfaction and performance in women's interscollegiate field hockey teams. Journal of Sport Psychology, 4, 324-337.

YUKELSON, D., WEINBERG, R. \& JACKSON, A. (1984). A multidimensional group cohesion instrument for intercollegiate basketball. Journal of Sport Psychology, 6, 103-117. 